\title{
Earthquake mechanism and characterization of seismogenic zones in south-eastern part of Romania
}

\author{
Mircea Radulian ${ }^{1,2, *}$, Andrei Bălă ${ }^{1}$, Emilia Popescu ${ }^{1}$, Dragos Toma-Dănilă ${ }^{1}$ \\ ${ }^{1}$ National Institute for Earth Physics, Măgurele, Romania \\ 2 Academy of Romanian Scientists, Bucharest, Romania
}

\author{
Article history \\ Received May 6, 2017; accepted January 22, 2018. \\ Subject classification: \\ Earthquake mechanism; Seismogenic zone; Fault plane; Solution diagram.
}

\begin{abstract}
Earthquake mechanism information is fundamental to determine the stress field and to define seismogenic zones. At the same time, it is a basic input to compute seismic hazard by deterministic approach. The present paper extends the catalogue of the fault plane solutions for the earthquakes in Romania, previously completed until 1997, for 1998 2012 time interval. The catalogue is limited geographically to the Carpathians Orogeny and extra-Carpathians area located in the southeastern part of Romania because similar investigations cover the rest of the country. The catalogue comprises 259 intermediate-depth seismic events and 90 crustal seismic events, recorded in the considered time interval with acceptably constrained fault plane solutions (minimum 10 reliable polarities, small ratio of rejected polarities versus input polarities and non-zero focal depth). We use specific graphical tools in order to emphasize statistically representative features of the stress field as coming out from our results. The fault plane solutions of the Vrancea earthquakes generated in a confined sinking plate in the mantle reflect the dominant geodynamic process in the study region. The typical features revealed by all the previous studies on the subcrustal seismic ac tivity (predominant dip-slip, reverse faulting, characterizing both the weak and strong earthquakes) are reproduced as well by our investigation. As concerns the earthquake activity in the crust, a few new refined aspects are highlighted in the present work: (1) a deficit of the strike-slip component over the entire Carpathians foredeep area, (2) different stress field pattern in the Făgăraș-Câmpulung zone as compared with the Moesian Platform and Pre-Dobrogean and Bârlad Depressions, (3) a larger range for the dip angle of the nodal planes in the Vrancea subcrustal source, $\sim 40^{\circ}-70^{\circ}$ against $\sim 70^{\circ}$, as commonly considered.
\end{abstract}

\section{Introduction}

The present paper is an extension of previous studies dealing with the focal mechanism and related stress characteristics for the earthquakes recorded in Roma- nia [e.g., Radulian et al. 1999, 2002, Bala et al. 2003]. Thus, the catalogue of the fault plane solutions built up until 1997 is updated and expanded for the time interval 1998 - 2012 and subsequently analyzed in correlation with specific cluster of events and active faults.

We limit geographically our data set to the Carpathians Orogeny and extra-Carpathians area located in the south-eastern part of Romania. The seismogenic zones located in the study area, as defined by Radulian et al. [2000] and slightly changed here, are (see Figure 1): Moesian Platform (MO), Pre-Dobrogean Depression (PD), Barlad Depression (BD), Fagaras - Campulung area (FC) and Vrancea intermediate-depth source (VNI). Similar investigations were carried out by Oros et al. (2008a, 2008b), focused on the seismogenic zones located in the western part of Romania: Danubian area (DA) and Banat area (BA) (see inset of Figure 1). Their results (140 earthquakes mechanisms) can be considered as a complement to our work in order to characterize the earthquake mechanism data for the entire Romania. An area that remains still uncovered includes the Transylvanian Depression (TD) and Crisana - Maramures (CM) region (north-western Romania) where we could not get enough data to compute reliable fault plane solutions.

The analysis carried out by Sandu and Zaicenco [2008] for the time interval 1967 - 2006 covers roughly the same geographical area (lat. $44^{\circ}-50^{\circ} \mathrm{N}$, lon. $24^{\circ}$. $\left.30^{\circ} \mathrm{E}\right)$. Sandu and Zaicenco analyzed 10 different catalogues, identified differences between them and compiled a unified catalogue of the fault plane solutions using the polarities of the $\mathrm{P}$ waves reported in ISC bulletin as primary data. In the common time interval covered by 
the two investigations (1998 - 2006) the number of fault plane solutions in Sandu and Zaicenco [2008] is significantly smaller than in the present analysis: solutions for 30 events (29 of Vrancea intermediate-depth source and a single crustal event) compared to 358 events (out of which 94 crustal events). Since their work is based on the ISC data, the fault plane solutions are available only for larger events (i.e., $\mathrm{M}_{\mathrm{w}}>3.6$ ), while the most of the crustal earthquakes considered in this paper are below this magnitude. Also, the polarity accuracy is likely to be worse when using ISC data, as proved by the greater proportion of inconsistent polarities.

The earthquake mechanisms are computed in all cases using the SEISAN algorithm [Havskov and Ottemöller 2001] and the polarities of the first P-wave arrivals. The catalogue of fault plane solutions, presented in the Appendix $\mathrm{A}$ and accessible on line at www.infp.ro, comprises 264 intermediate-depth seismic events and 94 crustal seismic events, recorded in the time interval 1998 - 2012 (see also Table 1). We selected only the solutions with minimum 10 reliable polarities and acceptable stations coverage and with non-zero focal depth: 259 intermediate-depth +86 crustal events. The location of the events is presented in Figure 1.

Most of the study crustal earthquakes belong to the background seismicity, with magnitudes $\mathrm{M}_{\mathrm{w}}$ below 4, except the event of 3.10.2004 in the Northern Dobrogea with $\mathrm{M}_{\mathrm{w}}=4.9$. Almost three thirds of earthquakes occurred in the Vrancea region (VRI) in the mantle range (64 to $167 \mathrm{~km}$ depth, Table 1). Most of them have magnitudes $M_{w}$ below 5 , with only 5 earthquakes with magnitudes $M_{w} \geq 5$. The largest earthquake was recorded on 27.10.2006 with $\mathrm{M}_{\mathrm{w}}=6$.

The crustal earthquakes follow closely the areal distribution of the seismogenic zones, which were set on the basis of seismicity trends as resulting from the entire catalogue of earthquakes in Romania and on the basis of geotectonic grounds. Histograms of the earthquakes in the Vrancea subcrustal region and of the earthquakes in the adjacent crustal region on depth and size are plotted in the Figure 2. The number of events are computed on bins of $5 / 10 \mathrm{~km}$ on depth for crustal/subrustal events and 0.4 on magnitude.

\section{Seismicity distribution}

Seismicity in Romania is concentrated at the Carpathians Arc bend in the Vrancea region. Here, an isolated lithospheric slab downgoing in the mantle is permanently releasing seismic energy in an extreme narrow volume. In average, three earthquakes with

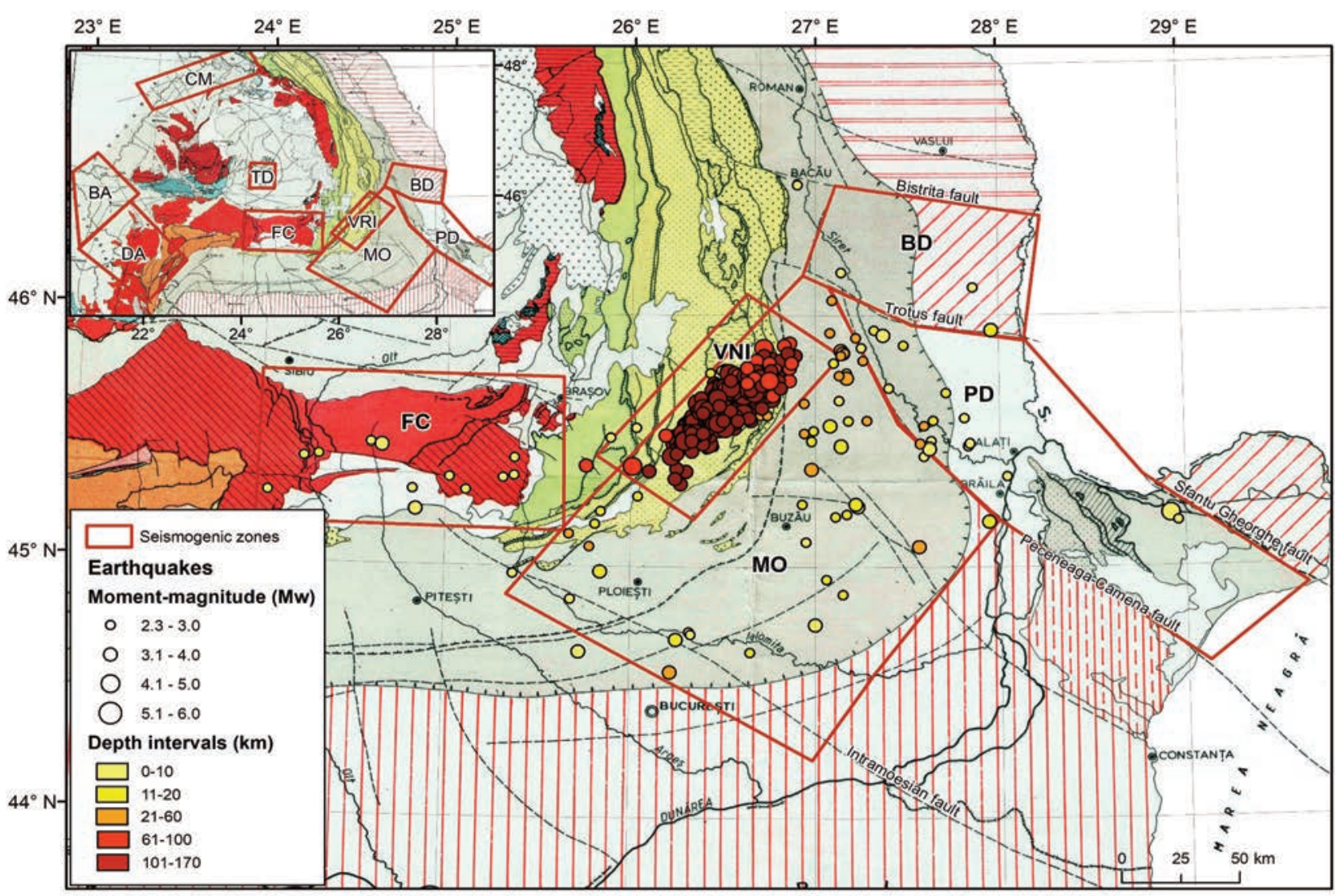

Figure 1. Tectonic map of the south-eastern part of Romania [after Sandulescu 1984] and the epicentre location for the earthquakes considered in this paper [in agreement with the ROMPLUS Catalogue, Oncescu et al. 1999, updated on http://www.infp.ro/romplus]. The seismogenic zones for the entire Romania are plotted in the top-left inset. 


\begin{tabular}{|c|c|c|c|c|}
\hline Seismogenic zone & No. events & $\mathbf{M}_{\mathrm{w}}$ & Depth $[\mathrm{km}]$ & No. stations \\
\hline Moesian Platform - MO & 39 & $2.3-3.3$ & $2-38$ & $10-51$ \\
\hline $\begin{array}{l}\text { Pre-Dobrogean Depression \& } \\
\text { Barlad Depression } \\
\text { PD-BD }\end{array}$ & 29 & $2.3-4.9$ & $0-46$ & $10-25$ \\
\hline Fagaras - Campulung area - FC & 18 & $2.3-3.3$ & $0-25$ & $10-34$ \\
\hline $\begin{array}{l}\text { Vrancea intermediate-depth } \\
\text { source - VNI }\end{array}$ & 259 & $2.7-6.0$ & $64-167$ & $10-60$ \\
\hline
\end{tabular}

Table 1. Number of earthquakes recorded between 1998 and 2012, with reliable fault plane solutions, associated with the study seismogenic zones.
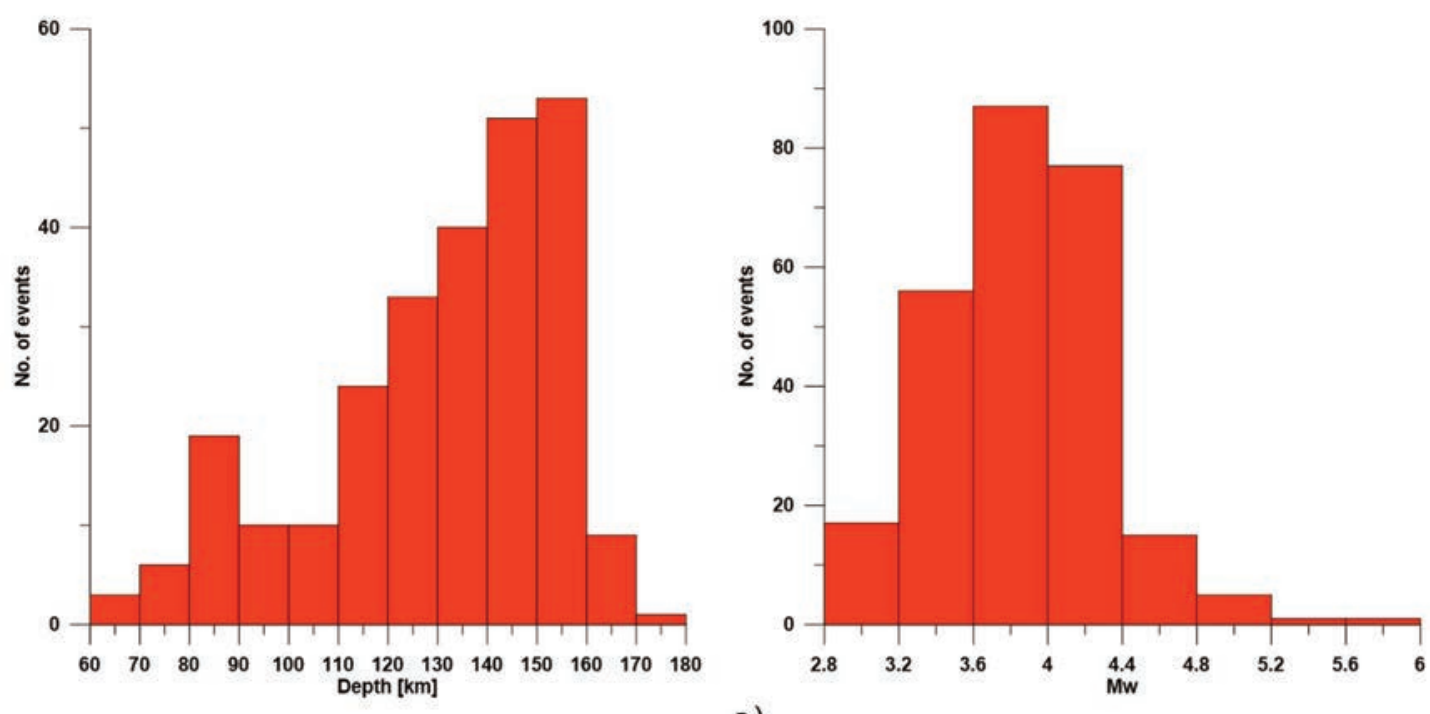

a)
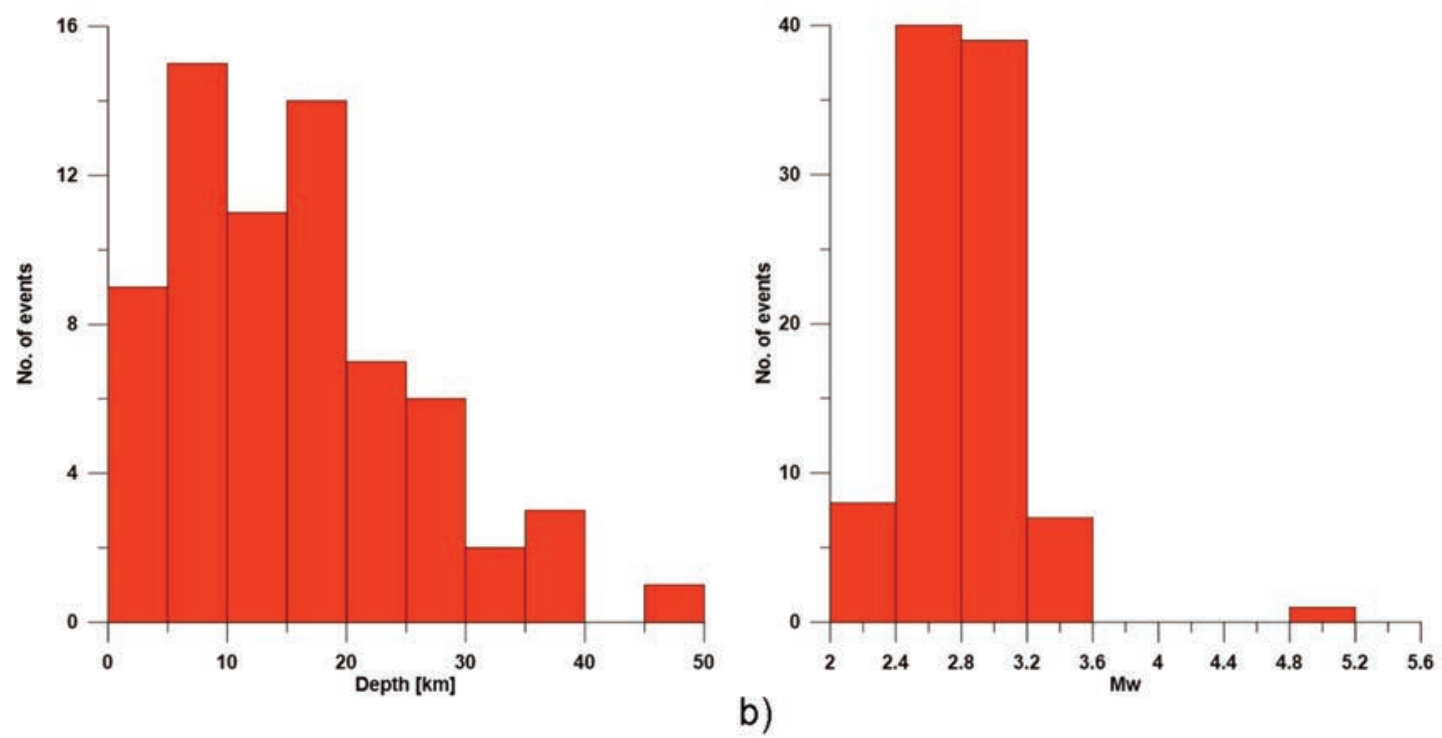

Figure 2. a) Histograms of the earthquakes of VNI zone (264 events) on depth and magnitude; b) Histograms of the crustal earthquakes (94 events) on depth and magnitude 
magnitude above 7 were reported each century for a time span of six centuries.

The origin of intermediate-depth seismicity in the Vrancea area is still an ongoing debate. The lithospheric volume which is seismically active can be approximated by a prism vertically oriented between 60 and $170 \mathrm{~km}$ depth, with a horizontal cross section of $30 \times 70 \mathrm{~km}^{2}$. Above $60 \mathrm{~km}$ and below $170 \mathrm{~km}$ the seismicity is suddenly cut off, although the high-velocity body, as determined by seismic tomography, extends notably beyond these limits [Martin et al. 2006, Ren et al. 2012].

The seismic activity in the crust is dispersed over the Carpathians orogeny and foreland with significant enhancements in several seismogenic zones, as defined first by Radulian et al. [2000]: EV - the area in the front of the South-Eastern Carpathians Arc bend, FC - the Făgăraş Mountains zone which is prolonging across Carpathians towards Campulung city, PD-BD - Pre-Dobrogean and Barlad Depression zones, which belong to the same tectonic unit (Scythian Platform), BA - Banat zone, DA - Danubian zone and CM - Crişana - Maramureş zone. The crustal earthquakes are commonly small to moderate $\left(M_{w}<6\right)$. Only in the FC zone a few shocks of magnitude above $6(\mathrm{Mmax}=6.5)$ were reported in the Romanian catalogue, in about one millennium time interval [Oncescu et al. 1999]. The crustal seismicity is generally associated with the basement fracture systems [Bala et al. 2015].

In the Figure 1 we focus our attention on the seismogenic zones located in the south-eastern part of Romania. The positioning of the other seismic areas is represented in the Figure 1 after Radulian et al. [2000]. Given that tectonically and geologically the seismogenic areas situated in front of the Carpathians Arc, south of the Peceneaga-Camena fault in the Moesian Platform, do not differ notably, we prefer to consider in our subsequent analysis a single area (MO) in this region. In the same way, we combined the Pre-Dobrogean Depression and Bârlad Depression zones into a single area (PD-BD). The Vrancea zone (VNI) and Făgăraş-Câmpulung zone (FC) are the same as defined in Radulian et al. [2000]. We slightly adjusted the Pre-Dobrogean zone, which was extended to the north-west in order to cover also the North Dobrogea Orogeny and to have a common margin with Barlad Depression zone and to be extended over the southern flank of Sf. Gheorghe fault (Figure 1). The adjustments relative to the previously defined seismogenic zones are made to include all the earthquakes in the catalogue and to keep at the same time their adherence to a specific tectonic province.

The eastern sector of the Moesian Platform, located between the Intramoesian fault and Peceneaga-
Camena fault, is more seismically active as compared with the sector located west of the Intramoesian fault, which is almost aseismic. The seismicity concentrates close to the Carpathians Arc bend, overlapping to some extend the epicentral area of the Vrancea subcrustal earthquakes. Quite frequently, the earthquakes are generated in moderate size sequences. Typical sequences were recorded in the Focşani - Râmnicu Sărat and Vrancioaia areas [Popescu and Radulian 2001, Popescu et al. 2012]. Many times, the earthquake sequences in front of the Carpathians Arc bend display alignments parallel to the orogen, probably in connection to a system of buried faults beneath the Focşani sedimentary basin [Hauser et al. 2001, Răileanu et al. 2005].

The Intramoesian fault crosses the Moesian Platform on the SE-NW direction separating two distinct sectors with different constitution and structure of the basement. Although it is a major fault, which extends from the continental platform of the Black Sea to the NW under the Getic Nappe [Sandulescu 1984] and which is supposed to reach in depth the lithosphere base [Enescu 1992], the associated seismicity is weak and scarce.

A deficit in seismicity is noticed to the west of the Intramoesian fault which extends over the entire western sector of the Moesian Platform until it comes into contact with the Southern Carpathians in the Danubian region (DA in Figure 1). For the seismogenic zones located in the western part of Romania, see Oros et al. [2008a and 2008b].

The Peceneaga-Camena fault separates the Moesian Platform unit from the North Dobrogean Orogen. The seismic activity to the northern side of the Peceneaga-Camena fault cover roughly three tectonic units: North Dobrogean Orogen; Pre-Dobrogean Depression and Bârlad Depression. The Pre-Dobrogean Depression lies to the north North Dobrogean Orogen, being separated from it by Sf. Gheorghe fault. The Pre-Dobrogean Depression is continuing to the north-west into Bârlad depression, which is north of Trotus fault [Figure 1, after Sandulescu, 1984].

The Bârlad Depression is a subsiding depression on the Scythian Platform in contact to the north with the southern edging of the East European Platform (Moldavian Platform). As was also noted by other studies [Radulian et al. 2002], the seismicity and focal mechanism features in the PD and BD zones are similar, and therefore, we can merge them in a single seismic active area (PD-BD), which includes also the North Dobrogean Orogen.

The Făgăraş-Câmpulung area is the eastern seismic active segment of the Southern Carpathians. It is char- 
acterized by strong shocks that reached up to $\mathrm{M}_{\mathrm{w}} \sim 6,5$ (the maximum magnitude recorded in Romania for crustal earthquakes). The last major seismic event was recorded on 26 January $1916\left(\mathrm{M}_{\mathrm{w}}=6.4\right)$ and it was followed by a significant aftershock activity which lasted several weeks [Atanasiu 1961]. The earthquakes generated in the south-eastern corner of this zone could be eventually associated with the north-western edge of the Intramoesian fault. A large sequence started on 4 May 1993 in the area and lasted through the entire year [maximum magnitude $\mathrm{M}_{\mathrm{w}} 4.7$, estimated using the seismic moment computed by Enescu et al., 1996]. The events occurred since 1993 to the present did not exceed magnitude 3.5 [Oncescu et al. 1999].

\section{Fault plane solutions}

We follow the convention of Aki and Richards [1980] to define the nodal plane parameters (strike, dip and rake). The hanging-wall block of the fault is always located to the right, and the footwall block to the left. That means that fault dips always to the right side of the trace when moving along the trace in the strike direction and the rake (which gives the slip direction) is defined as the movement of the hanging wall relative to the footwall block. Rake is measured on the fault plane of the fault relative to the fault strike, $\pm 180^{\circ}$. Positive rake values indicate thrust or reverse motion on the fault (the hanging wall is moving up), while negative rake values indicate normal motion on the fault (the hanging wall moved down).

The fault plane solutions are computed on the basis of the polarities of the first P-wave arrivals using the SEISAN algorithm [Havskov and Ottemöller 2001]. The regional velocity model used in the calculations is common for crustal and subcrustal earthquakes. It was estimated from local tomography data (CALIXTO experiment) for Vrancea region and surroundings as minimum 1 D model [Popa et al. 2001]. It is in a good agreement with the S-velocity model of Diehl et al. [2005] derived from the analysis of teleseismic recordings with the receiver function method of the 120 temporarily installed stations during CALIXTO experiment together with the permanent Romanian stations.

The computed fault plane solutions are plotted in the Figure 3. For a better graphical presentation/visualization, we kept for the Vrancea subcrustal earthquakes the mechanism solutions only for the larger events $\left(M_{w}>4.5\right)$, which are 22 subcrustal events out of 259 (Table 1). Several examples representative for crustal events located in the study seismogenic zones are plotted in the Figure 4.

We can draw some conclusions from a simple vi- sual examination of the Figure 3:

- Prevalence of reverse faulting in the Vrancea subcrustal source

- A tendency of the nodal planes for the Vrancea subcrustal source to be oriented either parallel or perpendicular to the Carpathians Arc bend

- A large variety of fault plane solutions for the crustal events both as faulting type and nodal plane orientation

These issues have also been highlighted by previous studies on focal mechanism characterization [see Radulian 2014]. A more detailed inspection of the focal mechanisms will be presented in the following chapter.

\section{Focal mechanism uncertainties}

The fault plane solutions obtained in this paper are affected inevitably by errors. Errors should be significant especially for smaller events due to several factors: greater noise influence, reduced number of reliable stations, larger location errors, and so on. Our goal was to investigate particularly the statistical properties of the fault plane solutions and not to look into details on their consistency and reliability. For example, the output from FOCMEC program [Snoke et al. 1984] provides a family of possible solutions, given certain input specifications. The main criterium in selecting acceptable solutions is to minimize the number of polarities errors. However, FOCMEC does not provide a quality rank of the members of a family of solutions, as in our case, only polarity data (and not amplitudes) are used. Hence, we consider a solution is acceptable when the traces of possible solutions are located relatively close each other on the lower hemisphere. Under these circumstances, we simply pick out one of the possible solutions as the 'true' solution. A reasonable measure of the solution uncertainty should be the area covered by the family of possible solutions (smaller area meaning better constraint; at limit, we should have a single solution), but, as proved by other studies, the problem of stability of focal mechanism solution is complex and nonlinear and can depend on many factors [see Hardebeck and Shearer 2002, for example]. Thus, the errors in the assumed source location or the seismic-velocity model, which are not taken into account in FOCMEC procedure, can alter the pattern of observations on the focal sphere and therefore can change the best-fitting focal-mechanism solution. So, we are aware that using only P-wave polarities does not assure the accuracy of the fault-plane solution even if a preferred solution relatively well constrained is obtained and mechanisms that are stable with respect to polarity errors may be unstable with respect to small changes in location or velocity model. 


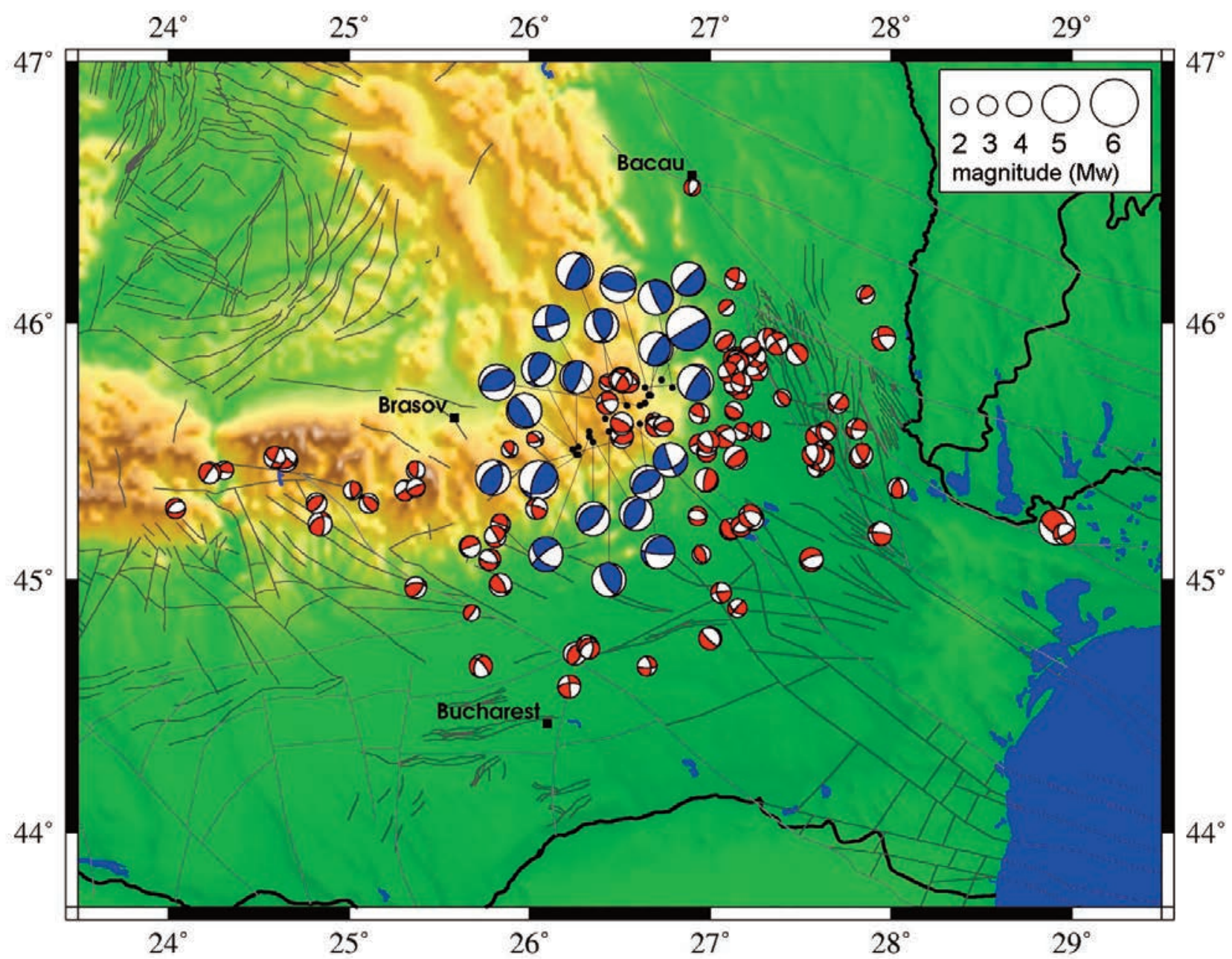

Figure 3. Focal mechanisms for 85 crustal earthquakes (red circles) and 22 intermediate depth earthquakes with $\mathrm{M}_{\mathrm{w}}>4.5$ (blue circles) from Vrancea intermediate-depth zone (VNI).

One way to solve this problem is that proposed by Hardebeck and Shearer [2002], who determined the stability of focal mechanism solutions by performing repeated trials with different possible event locations and seismic velocity models. In this approach, the preferred mechanism is taken to be the average of the set of acceptable mechanisms generated by each trial and only if the acceptable solutions are tightly clustered around the preferred mechanism the solution is considered stable and well constrained.

In our case, the only criteria that we used included the ratio of rejected polarities versus input polarities, station distribution and sensitivity of fault-plane solutions to including/removing key stations. The velocity model by Popa et al. [2001] was used in determination of takeoff angles for both Vrancea intermediate-depth events
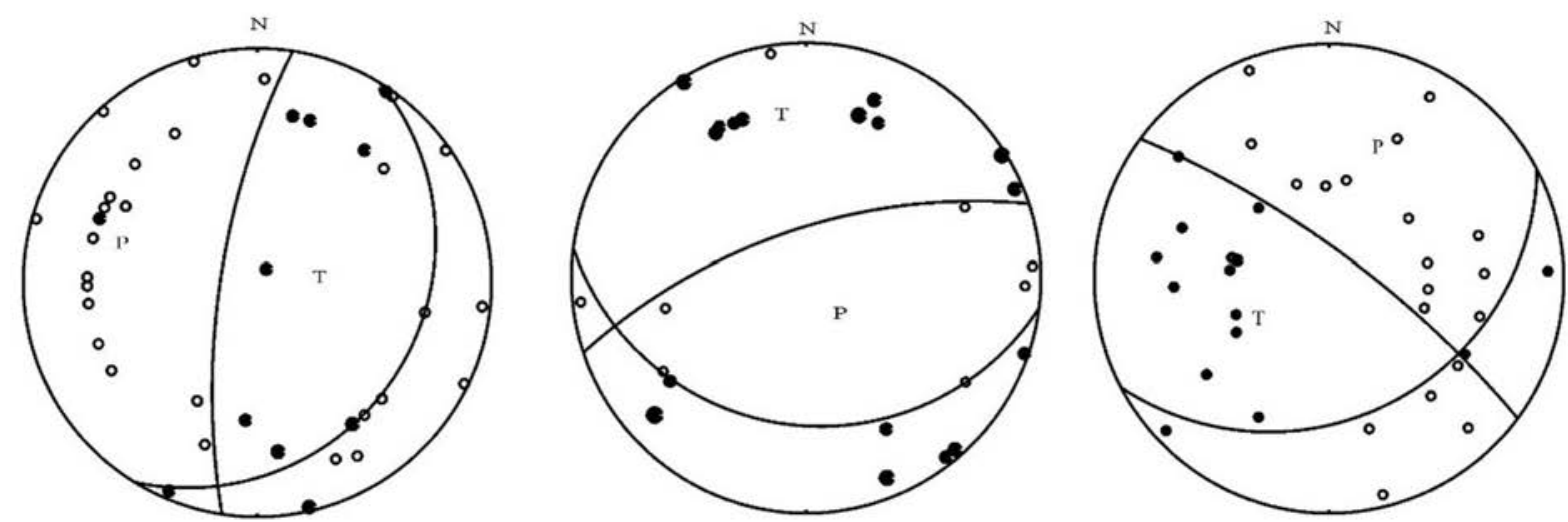

Figure 4. Examples of fault plane solutions for representative crustal events (2009/12/06 $\mathrm{M}_{\mathrm{w}} 3.3 \mathrm{MO}$ region - left, 2011/01/26 M $3.2 \mathrm{BD}$ $\mathrm{PD}$ region - middle, 2010/10/25 $\mathrm{M}_{\mathrm{w}} 3.2 \mathrm{FC}$ region - right). 
and crustal events. It is a regional model estimated from data recorded in the CALIXTO tomography experiment for the Vrancea area and around [Wenzel et al. 1998]. In all cases, we consider only clear P-wave polarities (weight assigned to unity), either of emergent or impulsive character, in order to increase the chance of getting meaningful solutions. Focal mechanisms can be reliably determined only for events with first-motion observations that adequately sample the focal sphere. The maximum gap in the source-to-station azimuth is required to be $<$ $90^{\circ}$, and the maximum gap in takeoff angle is required to be $<60^{\circ}$, (i.e., the takeoff angles cannot be all near horizontal or all near-vertical). In the present approach we limit the selection criteria to (1) minimum 10 reliable polarities, (2) acceptable ratio of rejected polarities versus input polarities and (3) non-zero focal depth. Applying these criteria to our database (Appendix A), we remove 13 events assigned as less reliable solutions (LR index in the last colon of Appendix A). We are aware that all these measures solve only part of the problem of uncertainties. Duputel et al. [2012] stressed, among others, the importance of associating realistic error analyses with any source inversion. They showed that in order to get reliable solutions through inversion, the error estimation should be part of the solution.

\section{Statistical analysis}

One of our goals is to determine the main features of the parameters of the fault plane solutions computed in this paper and to compare the results with previous investigations. For this purpose, we used graphical tools able to emphasize statistically representative features in our data set for each seismogenic area considered in the study. In this way, simple polar diagrams were employed to describe strike and dip behavior of the events in each active area. In order to classify the type of faulting, we represent the distribution of the principal axes $\mathrm{P}$, T and B using Kaverina et al. [1996] projection, which improves the Frohlich and Apperson [1992] ternary diagram. A dedicated program is employed for this purpose, which is described in Álvarez-Gómez [2014 and 2015]. According to the program description [Álvarez-Gómez 2015], we can classify earthquakes in seven classes represented by specific rupture types: 1) Normal; 2) Normal - Strike-slip; 3 ) Strike-slip - Normal; 4) Strike-slip; 5) Strike-slip - Reverse; 6) Reverse - strike-slip and 7) Reverse (Figure 5).

\subsection{Vrancea subcrustal source - VNI}

The polar diagrams for the azimuthal distribution of the two nodal planes ( $\mathrm{A}$ and $\mathrm{B}$ ) and for the plunge angle are plotted in the Figure 6 . Note the predomi-

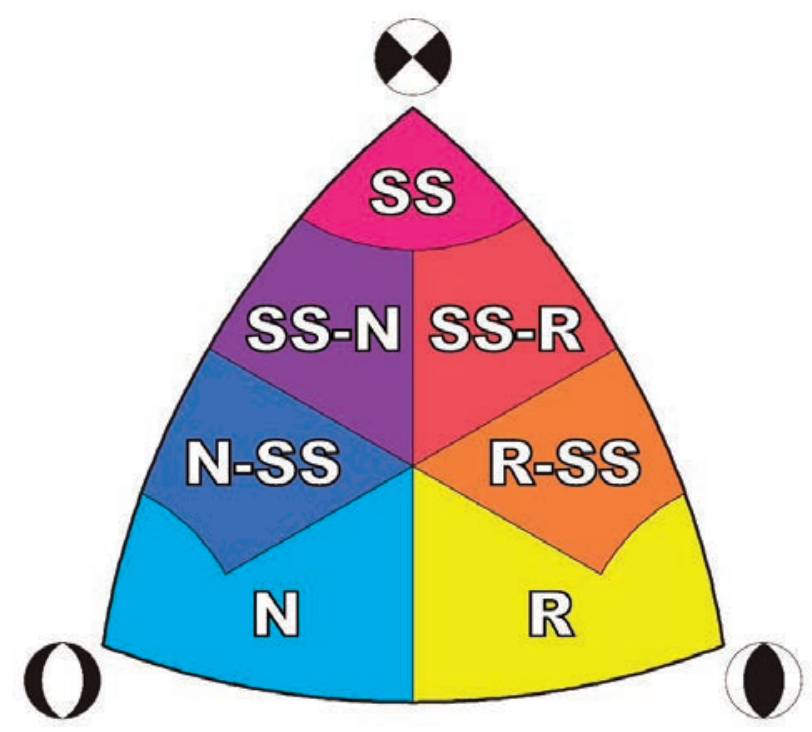

Figure 5. Classification diagram. N: Normal; N-SS: Normal Strike-slip; SS-N: Strike-slip - Normal; SS: Strike-slip; SS-R: Strikeslip - Reverse; R-SS: Reverse - strike-slip; R: Reverse [after ÁlvarezGómez 2015].

nance of nodal planes oriented NE-SW, parallel to the Carpathians Arc bend and the prevalence of plunge angles around $45^{\circ}$.

It is worth mentioning that this geometry of the faulting system corresponds with the orientation of the rupture faults for the largest Vrancea events [Enescu 1980, Oncescu 1987; Oncescu and Trifu 1987; Radulian 2014]. Taking into account the difference in scale between a moderate earthquake $\left(\mathrm{M}_{\mathrm{w}}=4-5\right)$ and a major earthquake $\left(\mathrm{M}_{\mathrm{w}}>7\right)$, it is not trivial such a feature. We may assume that the process of generating moderate earthquakes is controlled largely by the same tectonic forces as for generating the largest shocks.

The analysis of the Figure 6 reveals also a secondary tendency for the azimuthal orientation of the nodal planes, roughly perpendicular to the Carpathians Arc bend. This kind of focal mechanism is observed from time to time at moderate-to-large magnitudes $\left(\mathrm{M}_{\mathrm{w}} 5\right.$ to 7$)$. It looks like the rupture orientation and length scale with the seismicity geometry (elongated along NE-SW, see Figure 1): the rupture process propagates along NE-SW plane for most of the events, while for the smaller events propagate occasionally along a perpendicular direction (NW-SE).

Similar plots are provided by Bala et al. [2003] on the previous catalogue of Romanian earthquake mechanism solutions [Radulian et al. 2002], but their diagrams are represented on different depth segments (crustal and three subcrustal depth intervals). The diagrams for azimuth and dip angles only for mechanisms in Vrancea area are reported also by Sandu and Zaicenko [2008] on a different catalogue assembled from 10 different international catalogs. The angular dia- 

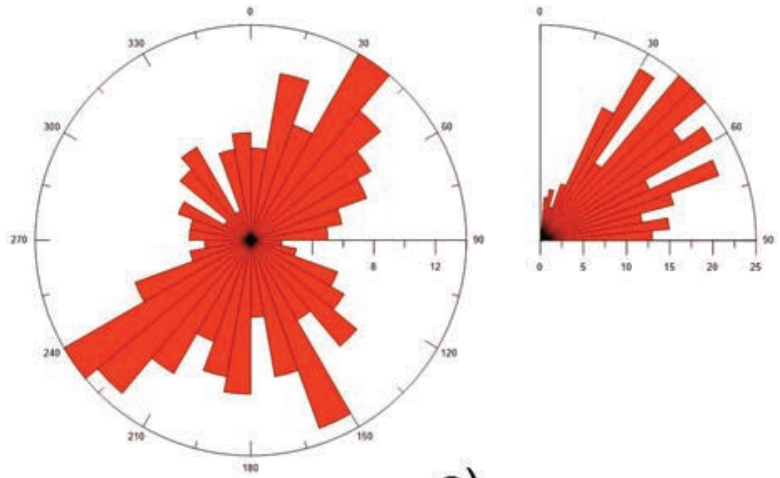

a)

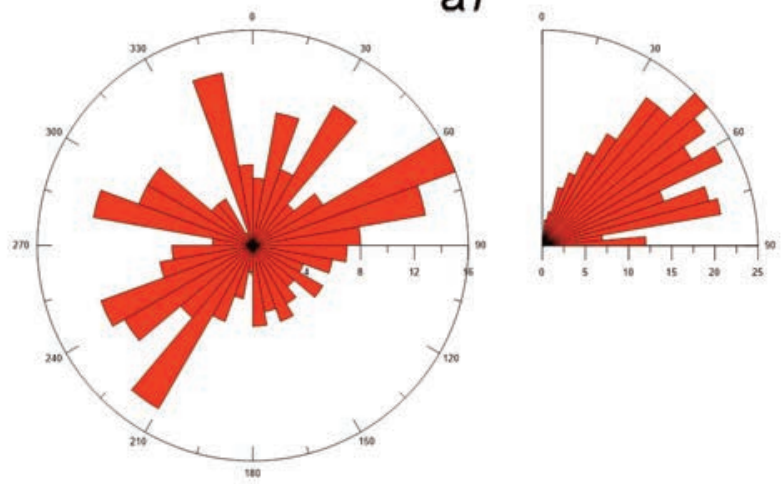

b)

Figure 6. Angular diagrams for azimuth and dip angles of the nodal planes - Vrancea subcrustal source (VNI): a) first nodal plane; b) second nodal plane.

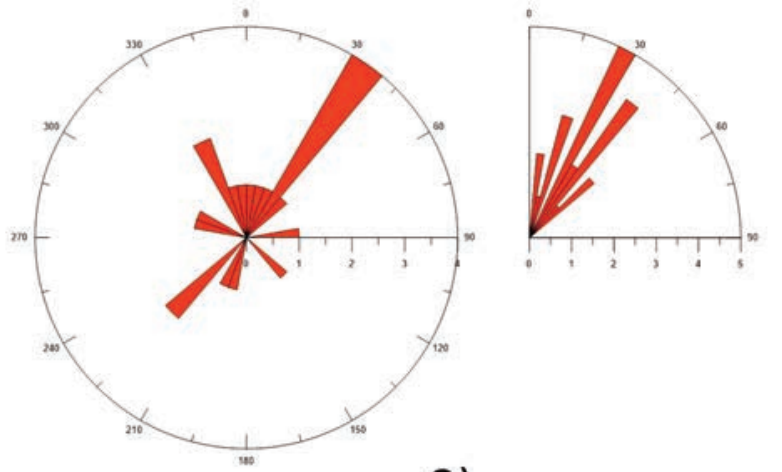

a)

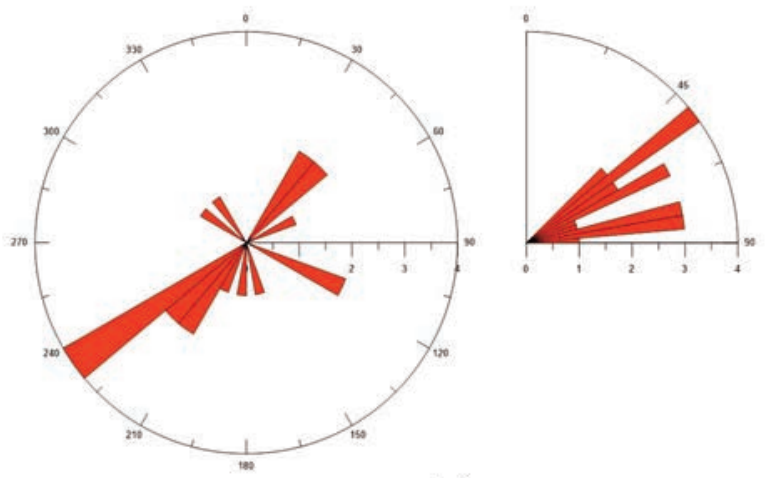

b)

Figure 7. Angular diagrams for azimuth and dip angles for Plane A (a) and plane B (b) for the CMT fault plane solutions of the Vrancea earthquakes with $4.7 \leq \mathrm{M}_{\mathrm{w}} \leq 7$. recorded between 1977 and 2013 .
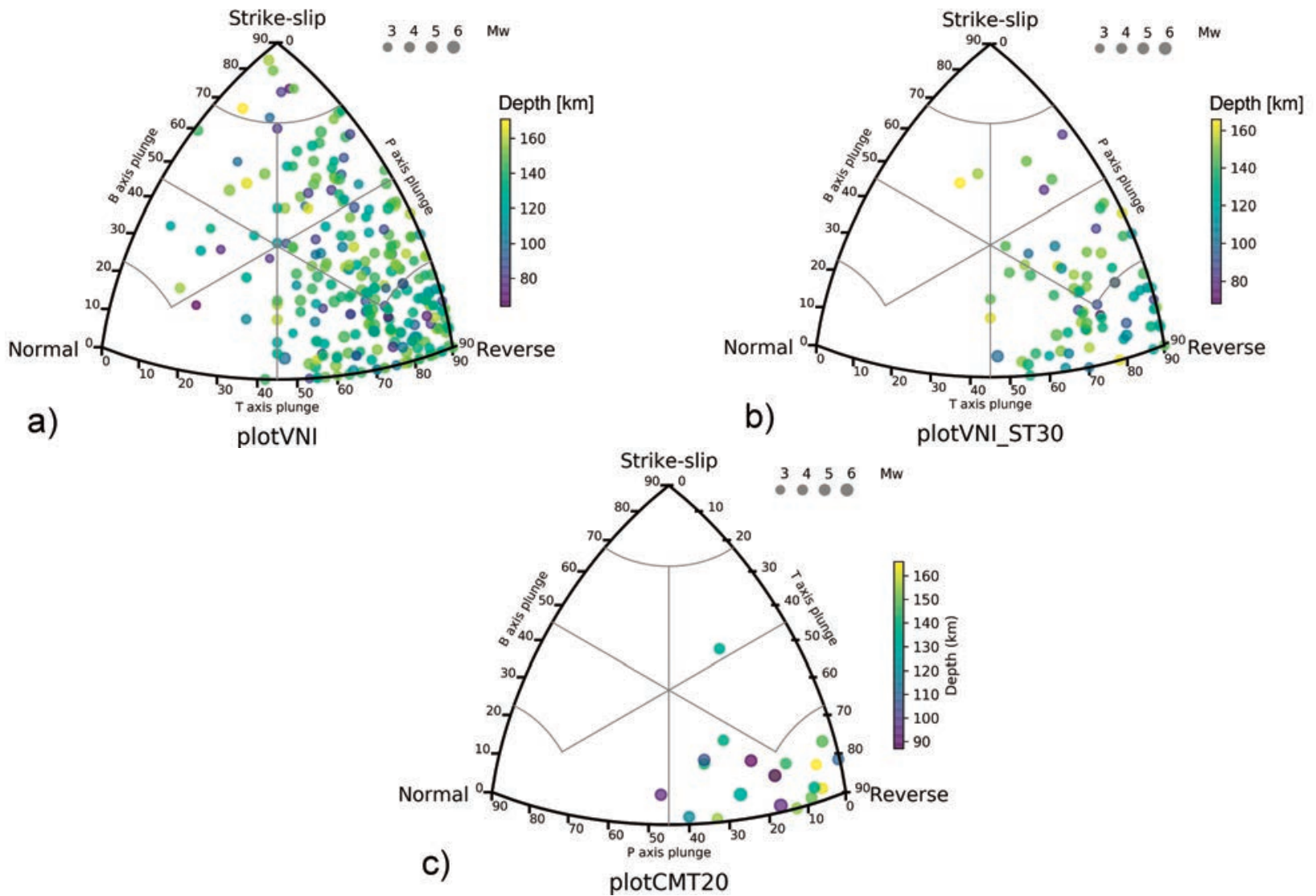

Figure 8. Diagram for P, T and B principal axes distribution for Vrancea zone (VNI). a). all the events; b). only events with at least 30 reliable polarities; c). the largest Vrancea events (CMT solutions). The dots are proportional to $\mathrm{M}_{\mathrm{w}}$ magnitude; to the right, the color scale represents the depths of the events in $\mathrm{km}$. 
grams for the largest Vrancea earthquakes $\left(\mathrm{M}_{\mathrm{w}} \geq 4.7\right)$ recorded between 1977 and 2013 based on the CMT fault-plane solutions (http:/ / www.globalcmt.org/) are plotted in the Figure 7. There are 20 events partly considered in the papers of Ganas et al. [2010] and Radulian [2014]. They show the same NE-SW tendency of fault plane orientation as for the entire data set of subcrustal earthquakes in Figure 6.

The distribution of the principal axes $\mathrm{P}, \mathrm{T}$ and $\mathrm{B}$, is represented in the Figure 8 for the entire data set (259 Vrancea intermediate-depth earthquakes) and for the fault plane solutions obtained with minimum 30 polarities (31 events) and for the CMT fault solutions (20 events). In order to classify the type of faulting we used the visualization procedure proposed by Kaverina et al. [1996]. Clearly, the reverse faulting is dominating in the Vrancea subcrustal source, independently of depth or magnitude ranges. This is even more evident when plotting only the events with best constraint fault plane solutions (minimum 30 polarities) or the largest Vrancea events. Practically, none of the events has well-defined normal or strike-slip faulting; two events, located at the bottom edge of the descending seismically active body, are characterized by strike-slip with normal components, and four events by strike-slip with reverse components. Whereas, most of the events have pure reverse faulting.

\subsection{Moesian Platform seismogenic zone - MO}

The earthquakes with computed focal mechanism that we consider to fit in the Moesian seismogenic zone are spread over a wide area, both to the south-east and south of the Vrancea region and covering all the eastern Moesian Platform (Wallachian sector), from Peceneaga Camena fault to Intramoesian fault (Figures 1,2). Most of them (36) are in connection with the Vrancea seismogenic area, while a few of them (6) can be rather associated to the Intramoesian fault area. The events are of small-to-moderate magnitude $\left(\mathrm{M}_{\mathrm{w}} \leq 3.3\right)$ belonging to the background seismicity. Four of them are main shocks of local earthquake sequences: 30 April 2004 (15 events), 29 November - 3 December 2007 (41 events), 6 - 30 September 2008 (42 events) and 6 December 2009 (23 events), while the other 38 are single events [Tugui et al. 2009, Popescu et al. 2011, 2012, Romplus earthquake catalogue: http: / / www.infp.ro/romplus/].

The polar diagrams for the azimuthal distribution of the two nodal planes (A and B) and for the plunge angle are plotted in the Figure 9. The azimuthal distribution of the nodal planes does not suggest a preferential orientation, but only a slight tendency to align perpendicularly to the Carpathians Arc bend. The di-
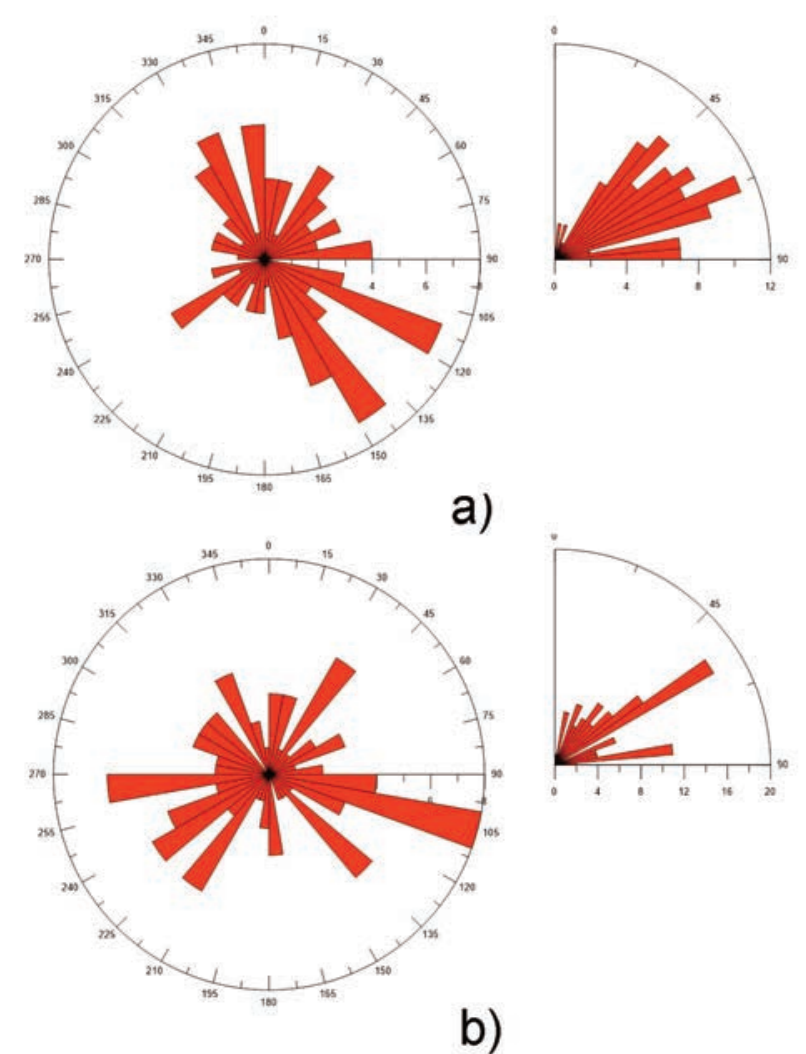

Figure 9. Angular diagrams for azimuth and dip angles of the nodal planes - Moesian Platform area (MO): a) first nodal plane; b) second nodal plane.

agram for $\mathrm{P}, \mathrm{T}$ and $\mathrm{B}$ axes (Figure 10) shows an equal distribution among normal and reverse faultings and absence of pure strike-slip faulting. According to our results, reverse and normal faulting are prevalent, with only small strike-slip influence, while pure strike-slip is missing.

5.3 Pre-Dobrogean Depression and Bârlad Depressions

The focal mechanisms were computed for 14 events located in the Predobrogean Depression and 14 events located in the Bârlad Depression. The diagram for $\mathrm{P}, \mathrm{T}$ and $\mathrm{B}$ axes (Figure 11) shows broadly the same features as for the Moesian Platform (Figure 10): an equal probability for normal and reverse faulting and almost total lack of pure strike-slip faulting. This result suggests that despite the lateral differences among the tectonic units acting in the foredeep area of the Carpathians the faulting processes are quite similar, with prevalent subsidence and folding mechanisms.

Due to the reduced number of earthquakes in this zone and to the fact that the orientation of the $\mathrm{P}, \mathrm{B}, \mathrm{T}$ axes is very much alike the distribution presented in Figure 10 for Moesian Platform zone, the polar diagrams are represented for all the crustal earthquakes considered in the two zones, a total of 68 events (Figure 12).

The distribution of dip angles in Figure 12 is close 


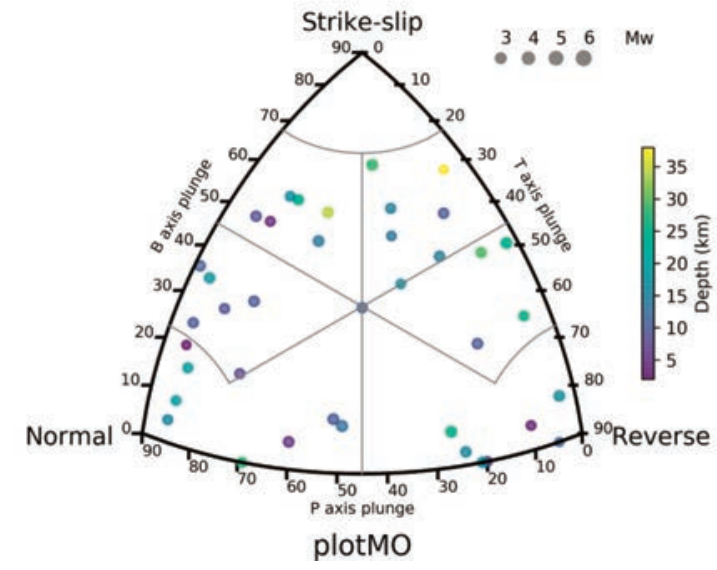

Figure 10. Ternary diagram for $\mathrm{P}, \mathrm{T}$ and $\mathrm{B}$ principal axes distribution for Moesian Platform seismogenic area (MO).
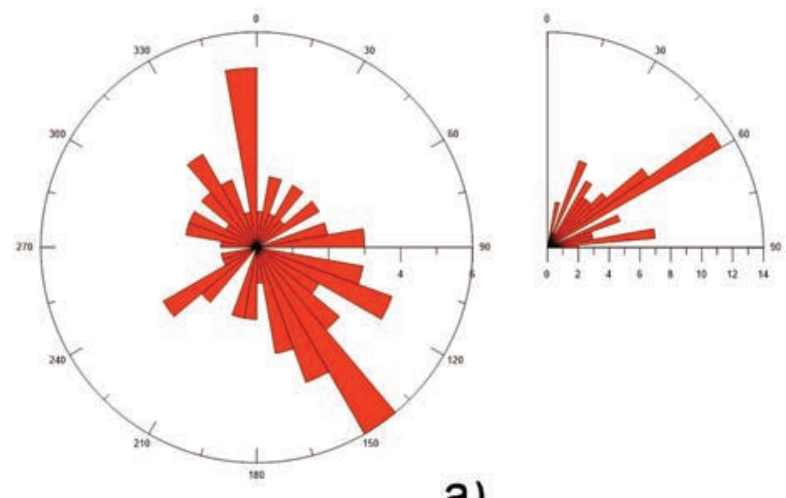

a)

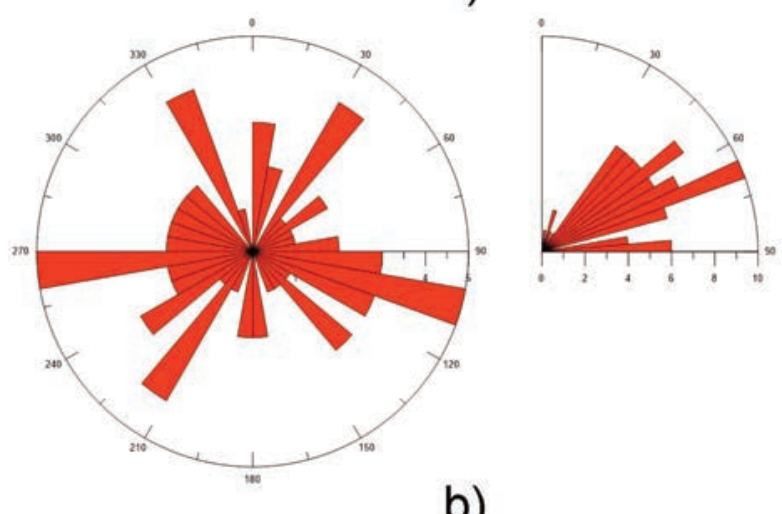

b)

Figure 12. Angular diagrams for azimuth and dip angles of the nodal planes - Moesian Platform area and PD-BD area: a) first nodal plane; b) second nodal plane.

to the distribution computed for 104 events in the same crustal region after the old catalogue of earthquake mechanisms [Bala et al. 2003], while the strike angles show the same almost equal distribution to all directions.

The corresponding ternary diagram for combined data from MO and PD-BD areas is represented the Figure 13. We show comparatively the diagram containing only the mechanisms with 20 or more reliable polarities (right side). Despite the poor statistics (17 events), the distribution of data points in this case keeps the same trends as in the complete diagram (left side).

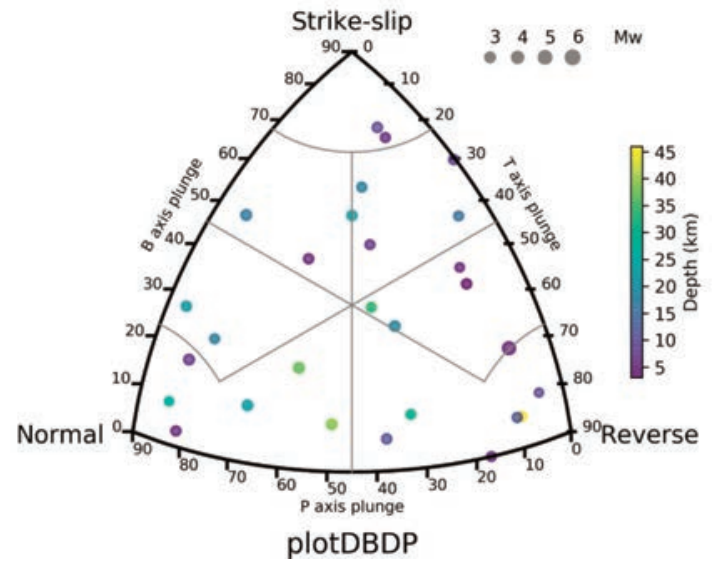

Figure 11. Diagram for $P, T$ and $B$ principal axes distribution for PreDobrogean and Bârlad Depressions.
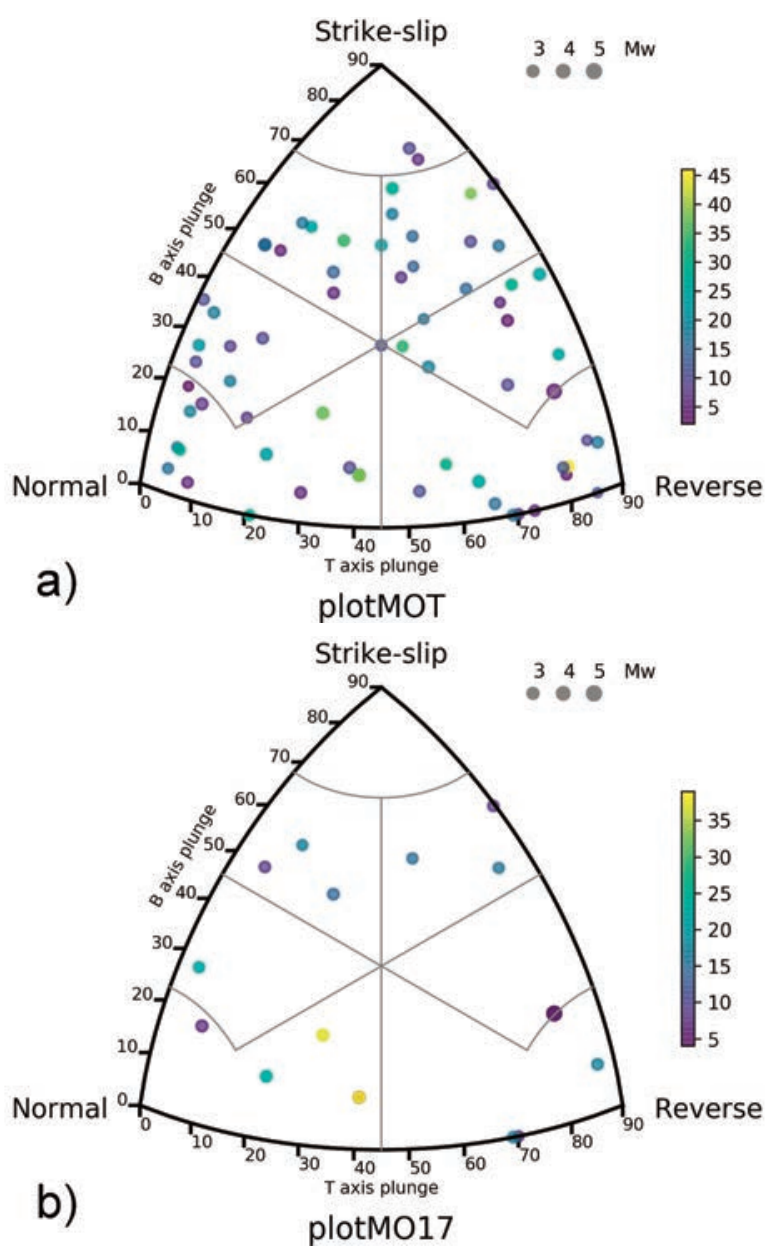

Figure 13. Ternary diagram for $\mathrm{P}, \mathrm{T}$ and $\mathrm{B}$ principal axes distribution for Moesian Platform seismogenic area (MO) and Pre-Dobrogean and Bârlad Depressions: a). for all events (67 events); b). diagram for the mechanisms with 20 or more reliable data (17 events).

\subsection{Făgăraș - Câmpulung seismogenic zone - FC}

The catalogue of earthquakes with computed focal mechanism belonging to the Făgăraş-Câmpulung seismogenic area includes 18 events, most of them located in the southern side, towards the contact between Făgăraş Mountains and Moesian Platform. All the events occurred in the 1998 - 2012 time interval belong to the 


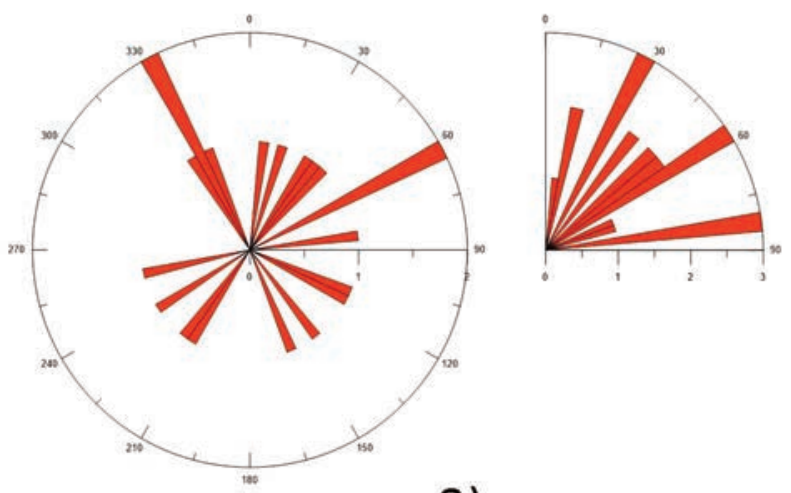

a)

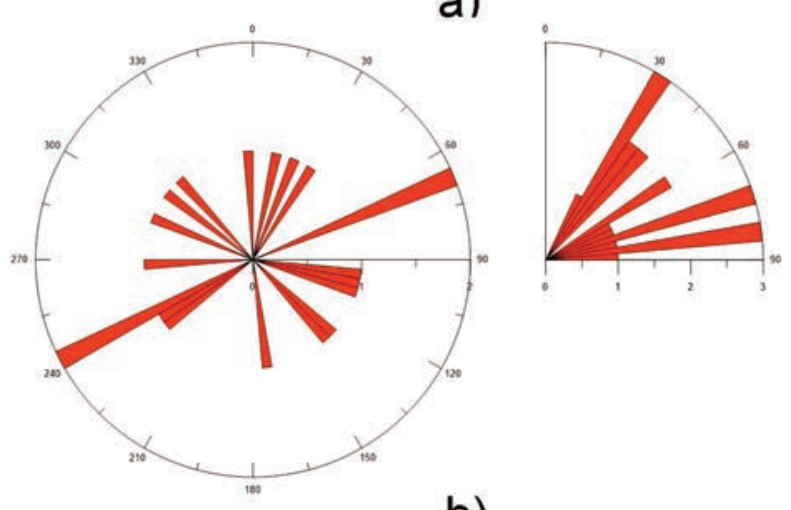

b)

Figure 14. Angular diagrams for azimuth and dip angles of the nodal planes for the events of Făgăraş - Câmpulung area (FC): a) first nodal plane; b) second nodal plane.

background seismicity (magnitudes no greater than 3.3). The polar diagrams for the azimuthal distribution of the two nodal planes (A and $B$ ) and for the plunge angle are plotted in the Figure 14. The statistics is too low to provide reliable trends in nodal plane orientation. Apparently, the fault planes are equally distributed on azimuth, while the dip angles have some three principal directions to 30,60 and $85^{\circ}$.

The picture shown by the diagram for $\mathrm{P}, \mathrm{T}$ and $\mathrm{B}$ axes (Figure 15) for the Făgăraş - Câmpulung area is somewhat different from that pointed out for the other seismogenic areas in the crust. It is closer to the typical distribution of the Vrancea subcrustal earthquakes, with a particular emphasis on reverse faulting component. This result suggests the prevalence of folding processes as a consequence of the convergent contact between Moesian Platform and Carpathians.

5.5 Crustal seismicity in the south-western part of Romania

To complete the image of focal mechanism characteristics for entire Romania, we shall discuss briefly the results obtained for the earthquakes recorded west of the Olt river (Oltenia region), in the Danubian zone (where Danube river is crossing the passage between Southern Carpathians and Balkans) and in the Banat region. The earthquake mechanisms for these events were described by Oros et al. [2008a and 2008b].

The seismicity observed west of Olt river is located in the crust and comprises small-to-moderate events. Only a few exceptions are reported for events with $\mathrm{M}_{\mathrm{w}}$ reater than 5.0 occurred in the Danubian zone and Oltenia [Atanasiu 1961, Oncescu et al. 1999]: at Mehadia-Baile Herculane $\left(\mathrm{M}_{\mathrm{w}}=5.6\right.$ in 1991), Moldova Noua $\left(\mathrm{M}_{\mathrm{w}}=5.3\right.$, in 1879) and nearby Tismana $\left(\mathrm{M}_{\mathrm{w}}=5.2 \mathrm{in}\right.$ 1943). A few more events above magnitude 5 have been located in the Banat area with the maximum magnitude $\mathrm{M}_{\mathrm{w}}=5.6$ (the event of 12 July 1991 near Banloc). Some epicenters of moderate events $\left(\mathrm{M}_{\mathrm{w}}=3.0-4.9\right)$ were located in the neighborhood of Targu Jiu city. In the south of Dolj county a few moderate earthquakes were felt between Craiova and Caracal cities.

The significant earthquakes from Oltenia and Danubian zone suggested by their focal mechanism a reverse faulting south of Turnu Severin and NW and SE of Targu Jiu and a normal faulting near Baile Herculane and south Craiova [see Oros et al. 2008a and 2008b, for details]. The earthquakes are generated by either the transverse fault systems of the platform or by the E-W fault systems along which the platform sinks underneath the Carpathian orogen. Other earthquakes could be generated at the contact of Getic and Danubian domains of Southern Carpathians, on the Timok and Jiu faults or in the Cerna graben [Bala et al. 2015].

Banat region has a larger dispersion of epicenters. The earthquake mechanism of the events located in Banat area are extensively described by Oros [2004], Oros et al. [2008a and 2008b].

The earthquakes in the Banat area are grouped into two main seismo-active tectonic setting defined by several studies as major seismogenic zones [Radulian et al 2000]. Thus, in the North-West the Banat seismogenic zone (BA) develops corresponding to a depression area (Western Plain of Romania) and in the South-East the Danube seismogenic zone (DA) overlaps the area of the Carpathians Mountains.

A strike slip faulting combined more or less with thrust faulting is pointed out by the focal mechanisms of the significant events. Banat earthquakes occurred at the contact between Carpathian and Pannonian basement (from Timisoara to Banloc, and north of Timisoara), as well as to the contact between unleveled basement blocks (like horsts and grabens) from Sannicolau Mare, Nadlag-Jimbolia, Arad-Vinga-Calacea, and on the Timis Valley at Faget [Polonic and Malita 1997, Bala et al. 2015].

\section{Conclusions}

The catalogue of the focal mechanism for the 
earthquakes recorded in Romania, available until 1997 [Radulian et al. 2002, Bala et al. 2003] is updated for the period 1998 - 2012. Thus, the fault plane solutions for 259 intermediate-depth earthquakes (Vrancea source) and 94 crustal earthquakes (Moesian Platform, Predobrogean Depression, Bârlad Depression and Făgăraş Câmpulung) are added to the existing catalogue (appendix A). The fault plane solutions are computed in all cases by inverting the polarities of the P-wave first arrivals manually picked up at the seismic stations of Romania, Republic of Moldova, Bulgaria and Ukraine (according to bilateral protocols, the National Institute for Earth Physics continuously exchanges data with the corresponding seismological institutes in the neighbouring countries). To this aim, the SEISAN algorithm [Havskov and Ottemöller 2001] was applied. Only the solutions with minimum 10 polarities, acceptable coverage on the lower hemisphere and non-zero focal depth were selected for our analysis.

A similar investigation, partly overlapping our study interval, was carried out by Sandu and Zaicenco [2008], but they used ISC polarity data. For this reason, their fault plane solutions are available only for larger events $\left(M_{w}>3.6\right)$, while the present work is based on near-field observations for smaller events which are statistically significant as background seismicity.

We draw our attention to the seismic areas located in the south-eastern Romania, including the Vrancea subcrustal source, Făgăraş - Câmpulung zone, located in the Southern Carpathians, and the crustal areas laying in the Carpathians foredeep region (outward of Carpathians Arc bend). The papers of Oros et al. [2008a, 2008b] have been focused on the other seismogenic areas, located at the western extremity of Southern Carpathians (Danubian area - DA) and Banat area (BA). For that reason, these areas were not considered in our analysis.

The seismic activity that took place between 1998 and 2012 was limited to moderate-size events. The largest event was generated on 27 October $2006\left(\mathrm{M}_{\mathrm{w}}=\right.$ 6.0 ) in the Vrancea subcrustal source. The largest event generated in the crust occurred on 3 Oct. $2004\left(\mathrm{M}_{\mathrm{w}}=\right.$ 4.9) in the Pre-Dobrogean Depression.

Certainly, the outcomes of this paper refer to a data set which happened to be small-to-moderate earthquakes (no event of magnitude above 6 was recorded within the study time interval 1998 - 2012). The comparison with largest earthquakes from the Vrancea subcrustal source, as shown in Figure 8, emphasizes features characterizing strong earthquakes that can be identified in the background activity as well. It remains an open question for future investiga- tions to what extent our conclusions keep valid for stronger earthquakes in the crust, where historical earthquakes of magnitude around 6.5 occurred.

We are aware of the critical issue of uncertainties which are inherent in any approach limited to using Pwave polarities alone. The main results of our investigation appear to be justified mainly by the number of events, simple statistical considerations. By enlarging our analysis to an extended catalogue of focal mechanisms, a sound base to improve considerably future development of our study will be provided.

A summary figure on the statistical analysis of the resulting fault plane solutions carried out for the study seismogenic zones using ternary diagrams for the principal axes is given in the Figure 16.

For the time interval considered and the related magnitude range, the fault plane solutions of the shallow earthquakes are more likely related to local secondary faults than to the major faults located in the Carpathians foredeep region. We can simply explain on this line the variety of solutions in the Moesian Platform, Pre-Dobrogean Depression and Bârlad Depression zones. As a general trend which is statistically consistent, note the deficit of strike-slip faulting. This result suggests the prevalence of subsidence and folding processes as stress release mechanisms in the entire Carpathians foredeep region, as well as in Moesian Platform and Barlad depression. The hypothesis raised by a few authors in the last century on a trans-current movement along the major faults, crossing the aria situated between the Black Sea and Vrancea [Roman 1973, Airinei 1977, Constantinescu and Enescu 1984, Enescu and Enescu 1993] is not supported by our results. On the other hand, possible transcurrent movement along these major faults, as suggested by some geotectonic studies [e.g. Matenco et al. 2007], could be accommodated at small scale by non-strike-slip motions due to lateral variations in the fault tracing or to transferring motion on smaller secondary satellite faults.

More than that, it appears that the seismic activity in the Moesian Platform zone is limited to the east by the Danube river, along which an important fault exists, Danubian fault, which is presumed to be a crustal tectonic feature. Although the tectonic provinces in the Central and Southern Dobrogea belong to the Moesian Platform, just a few earthquakes occurred here are reported in the ROMPLUS catalogue. So, it appears that the Danubian fault separates MO seismogenic zone from the more stable Central and Southern Dobrogea zones to the east. The two important Peceneaga Camena and Capidava - Ovidiu faults go into these zones (as can be clearly seen and monitored at 


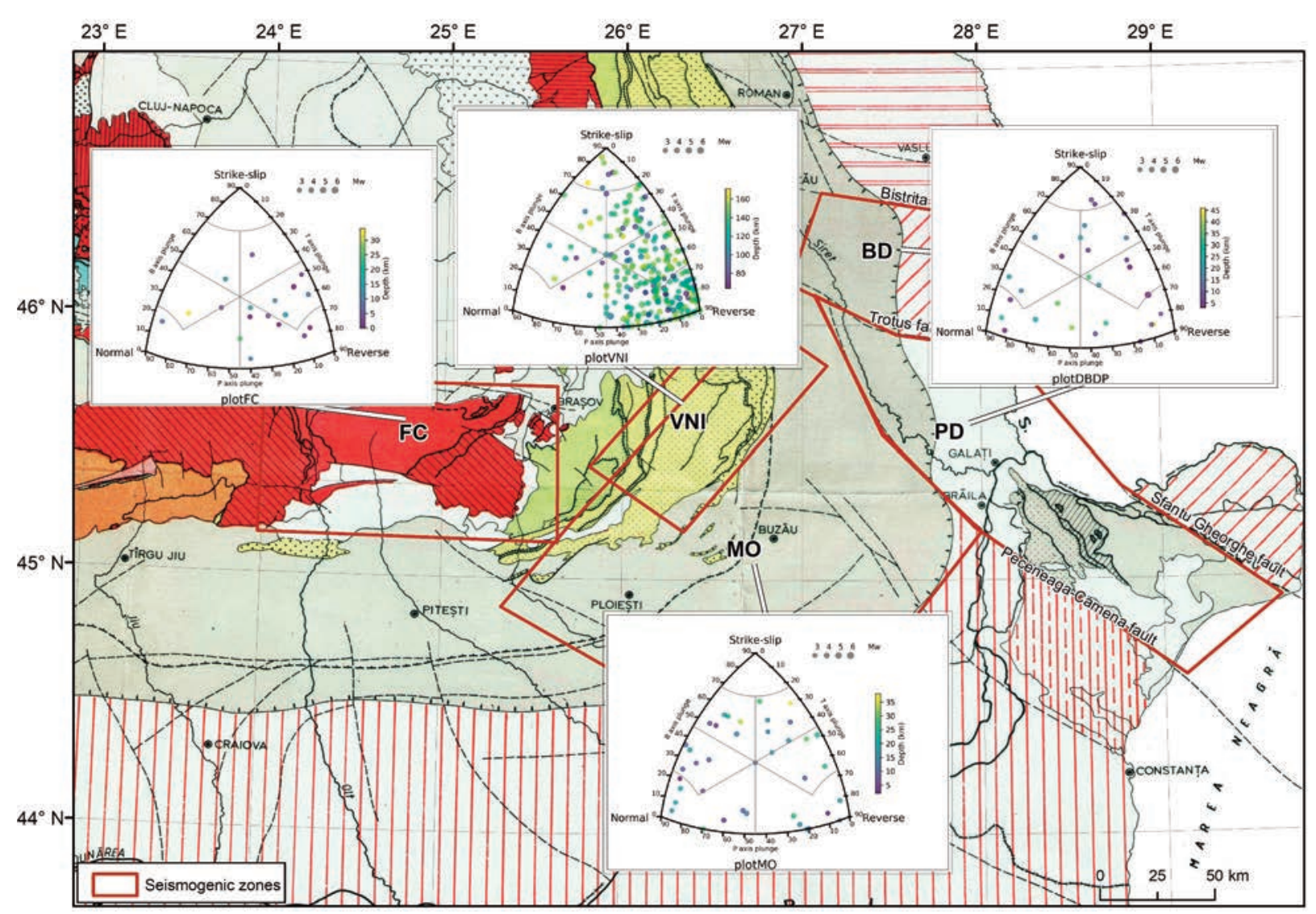

Figure 1. Ternary diagrams for the principal axes for the earthquakes considered in this paper associated to the seismogenic zones in the south-eastern part of Romania. Tectonic map is after Sandulescu [1984]. See above for more explanation on ternary diagrams.

surface on several sectors). However, the historic seismic activity along this faults in Dobrogea is clearly reduced, if we compare it to the seismic activity along Sf. Gheorghe fault in Northern Dobrogea (Figure 1).

The crustal seismic activity in this region can rather be seen as a response of the intense processes taking place beneath the Carpathians Arc Bend (Vrancea area) and materialized by a triple number of earthquakes occurred at intermediate depth in the same time interval, almost the same like in the previous catalogue [Radulian et al. 2002]. For the combined seismogenic areas MO and PD-BD (68 events) the distribution of the dip angles is close to the distribution find for 104 events in the same crustal region after the previous catalogue of earthquake mechanisms [Bala et al. 2003], while the strike angles show the same almost equal distribution to all directions.

Crustal earthquakes appear not to reflect the significant trans-current motions between the tectonic units in the region along the main faults, but they rather express the moving and re-positioning of different blocks in the area, delimited by either the main fault system, which runs parallel to the Carpathians Arc Bend or by secondary faults, distributed to a general direction which is roughly perpendicular to the direction of the main fault system.
The fault plane solutions of the Vrancea earthquakes generated in sinking plate in the mantle are preserving the typical features revealed by all the previous studies on the subcrustal seismic activity in the Vrancea region: predominant dip-slip, reverse faulting, characterizing both the weak and strong earthquakes [Enescu 1980, Oncescu 1987, Oncescu and Trifu 1987]. $\mathrm{T}$ axis close to vertical and $\mathrm{P}$ axis close to horizontal tending to be oriented perpendicularly to the Carpathians arc. The strong clustering of foci and the high rate of occurrence in time reveals a geodynamical process releasing very efficiently tectonic stresses. The continuous vertical or subvertical extension in the slab, in parallel with NW-SE predominant compression, can be associated with quite an extensive series of active models advanced recently:

1. A strong pull down by gravitational sinking into asthenosphere of an oceanic slab [Sperner et al. 2004];

2. An active continental lithospheric delamination [Knapp et al. 2005];

3. Dehydration of rocks [Ismail-Zadeh et al. 2000];

4. Gravitational instability [Lorinczi and Houseman 2009];

5. Thermal instability [Cloetingh et al. 2004, Demetrescu et al. 2007]. 
6. Unstable triple junction [Besutiu 2001].

The focal mechanism patterns obtained in the present study reproduce to a large extent the stress field characterization carried out by Radulian et al. [1999, 2000)], using essentially an independent catalogue of fault plane solutions from the period until 1997. However, the considerable increase of fault plane solutions accuracy for the earthquakes recently recorded, due to the significant improvement of the Romanian seismic network [Neagoe et al. 2014] and of their statistical representativeness, allows us to individualize a few refined aspects not obvious in the previous investigations, such as: (1) deficit of the strike-slip component over the entire Carpathians foredeep area, (2) different stress field pattern in the Făgăraş - Câmpulung zone as compared with the Moesian Platform and Pre-Dobrogean and Bârlad Depressions, (3) a larger range for the dip angle of the nodal planes in the Vrancea subcrustal source, $\sim 40^{\circ}-70^{\circ}$ against $\sim 70^{\circ}$, as commonly considered.

Acknowledgments. The database for this work is organized in Appendix A (http://www.infp.ro/) and it is part of this paper. The ternary diagrams in this paper are realized with a dedicated program which was kindly made available by the author and which is described properly in Álvarez-Gómez [2014]s. The work in this paper was realized in the frame of NUCLEU Program, project no. PN 16.35.01.08 and PN 16.35.01.03 (2016-2017, http:/ / nucleu2016.infp.ro/). We recognize the important contribution of the anonymous reviewers to significantly improving the quality of the paper.

\section{References}

Airinei, S. (1977). Lithospheric microplates on the Romanian territory reflected by regional gravity anomalies (in Romanian), St. Cerc. Geol., Geogr., Geofiz., 15, 19-30.

Aki, K. and P.G. Richards (1980). Quantitative seismology. Theory and Methods, W.H. Freeman, San Francisco.

Álvarez-Gómez, J. A. (2014). FMC: a one-liner Python program to manage, classify and plot focal mechanisms, Geophysical Research Abstracts, 16, EGU2014-10887.

Álvarez-Gómez, J.A. (2015). FMC A program to manage, classify and plot focal mechanism data, version 1.01, March 2015, Faculty of Geology. Universidad Complutense de Madrid.

Atanasiu, I. (1961). The earthquakes in Romania (in Romanian), Ed. Academiei, Bucharest, pp. 194.

Bala, A., M. Radulian and E. Popescu (2003). Earthquakes distribution and their focal mechanism in correlation with the active tectonic zones of Romania, Journal of Geodynamics, 36, 129-145.

Bala, A., V. Raileanu, C. Dinu, M. Diaconescu (2015). Crustal seismicity and active fault systems in Romania, Romanian Reports in Physics, 67, 1176-1191.

Besutiu, L. (2001). Vrancea active seismic area: a continental unstable triple junction?, Rev. Roum. Geophys., 45, 59-72.

Cloetingh, S. A. P. L., E. Burov, L. Matenco, G. Toussaint, G. Bertotti, P.A.M. Andriessen, M.J.R. Wortel and W. Spakman (2004). Thermo-mechanical controls on the mode of continental collision in the SE Carpathians (Romania), Earth and Planetary Science Letters, 218, 57-76.

Constantinescu, L. and D. Enescu (1984). A tentative approach to possibly explaining the occurrence of the Vrancea earthquakes, Rev. Roum. Geol., Geophys., Geogr., Ser Geophys., 28, 19-32.

Demetrescu, C., H. Wilhelm, M. Tumanian, S. B. Nielsen, A. Damian and V. Dobrică (2007). Timedependent thermal state of the lithosphere in the foreland of the Eastern Carpathians bend. Insights from new geothermal measurements and modelling results, Geophysical Journal International, 170, 896-912.

Diehl, T., Ritter, J. R. R. and the CALIXTO Group (2005). The crustal structure beneath SE Romania from teleseismic receiver functions, Geophys. J. Int., 163, 238-251.

Duputel, Z., Rivera, L., Fukahata, Y., Kanamori, H. (2012). Uncertainty estimations for seismic source inversions, Geophysical Journal International, 190, $1243-1256$.

Enescu, D. (1980). Contributions to the knowledge of the focal mechanism of the Vrancea strong earthquakes of March 4, 1977, Rev Roum. Géol Géophys Géogr Ser. Géophys., 24, 3-18.

Enescu, D. (1992). Lithosphere structure in Romania. I. Lithosphere thickness and averange velocities of seismic waves P and S. Comparison with other geophysical data, Rev. Roum. Phys., 37, 623-639.

Enescu, D. and B. D. Enescu B.D. (1993). Contributions to the knowledge of the genesis of the Vrancea (Romania) earthquakes, Romanian Reports in Physics, 45, 777 - 796.

Frohlich, C. and K. D. Apperson (1992). Earthquake focal mechanisms, moment tensors, and the consistency of seismic activity near plate boundaries, Tectonics, 11, 279 - 296.

Ganas, A., B. Grecu, E. Batsi and M. Radulian (2010). Vrancea slab earthquakes triggered by static stress transfer, Nat. Hazards Earth Syst. Sci., 10, 2565-2577. 
Hardebeck, J. L. and P. M. Shearer (2002). A new method for determining first-motion focal mechanisms, Bulletin of the Seismological Society of America, 92, 2264-2276.

Hauser, F., V. Răileanu, W. Fielitz, A. Bala, C. Prodehl, G. Polonic and A. Schulze (2001). VRANCEA99 - The Crustal structure beneath the southeastern Carpathians and the Moesian Platform from a refraction seismic profile in Romania, Tectonophysics, 340, $233-256$.

Havskov, J. and L. Ottemöller (2001). SEISAN: The Earthquake Analysis Software, Version 7.2, University of Bergen, Norway, 256 p.

Ismail-Zadeh, A.T., G. F. Panza,, B. M. Naimark, B.M. (2000). Stress in the descending relic slab beneath the Vrancea region, Romania, Pure and Applied Geophysics, 157, 111-130.

Kaverina, A. N., A. V. Lander and A. G. Prozorov (1996). Global creepex distribution and its relation with earthquake - source geometry and tectonic origin, Geophys. J. Int., 125, 249-265.

Knapp, J. H., C. C. Knapp, V. Răileanu, L. Maţenco, V. Mocanu and C. Dinu. (2005). Crustal constraints on the origin of mantle seismicity in the Vrancea Zone, Romania: The case for active continental lithospheric delamination, Tectonpohysics, 410, 311-323.

Lorinczi, P. and G.A. Houseman (2009). Lithospheric gravitational instability beneath the Southeast Carpathians, Tectonophysics, 474, 322-336.

Martin, M., F. Wenzel and the CALIXTO working group (2006). High-resolution teleseismic body wave tomography beneath SE-Romania - II. Imaging of a slab detachment scenario, Geophysical Journal International, 164, 579-595.

Matenco, L., G. Bertotti, K. Leever, S. Cloetingh, S. M. Schmid, M. Tarapoanca and C. Dinu (2007). Largescale deformation in a locked collisional boundary: Interplay between subsidence and uplift, intraplate stress, and inherited lithospheric structure in the late stage of the SE Carpathians evolution, Tectonics, 26, doi:10.1029/2006TC001951.

Oncescu. M. C. (1987). On the stress tensor in Vrancea region, J. Geophys. Res., 62, 62-65.

Oncescu, M. C. and C. I. Trifu. (1987). Depth variation of the moment tensor principal axes in Vrancea (Romania) seismic region, Ann. Geophysicae, 5B, 149-154.

Oncescu, M. C., V. Marza, M. Rizescu and M. Popa (1999). The Romanian earthquake catalogue between 983-1996, in Vrancea Earthquakes: Tectonics, Hazard and Risk Mitigation, F. Wenzel, D. Lungu, O. Novak (Editors), Kluwer Academic Pub- lishers, 43-49.

Oros, E. (2004). The April-August Moldova Noua earthquakes sequence and its seismotectonic significance, Rev. Roum. Geophys., 48, 49-68.

Oros, E., M. Popa and I. A. Moldovan (2008a). Seismological database for BANAT seismic region (ROMANIA) - Part 1: The Parametic Earthquake Catalogue, Romanian Journal of Physics, 53, 955-964.

Oros, E., M. Popa and I. A. Moldovan (2008b). Seismological database for BANAT seismic region (ROMANIA) - Part 2: The Catalogue of the Focal Mechanism Solutions, Romanian Journal of Physics, 53, 965-977.

Neagoe C., L. Manea and C. Ionescu (2014). Romanian Data Center: modern way for seismic monitoring, Abstract EGU2014-3320, EGU General Assembly, Vienna, 2014.

Polonic, G. and Z. Malita Z. (1997). Geodynamic processes and the seismicity in Banat (Romania), Revue de Geophysique, 41, 67-78.

Popa, M., E. Kissling, M. Radulian, K.-F. Bonjer, D. Enescu, S. Dragan and the CALIXTO Research Group (2001). Local source tomography using body waves to deduce a minimum 1D velocity model for Vrancea (Romania) zone, Romanian Report in Physics, 53, 519-536.

Popescu, E. and M. Radulian (2001). Source characteristics of the seismic sequences in the Eastern Carpathians foredeep region (Romania), Tectonophysics, 338, 325-337.

Popescu, E., C. Neagoe, M. Rogozea, I. A. Moldovan, F. Borleanu and M. Radulian (2011). Source parameters for the earthquake sequence occurred in the Ramnicu Sarat area (Romania) in NovemberDecember 2007, Romanian Report in Physics, 56, 265-278.

Popescu, E., F. Borleanu, M. Rogozea and M. Radulian (2012). Source analysis for earthquake sequence occurred in Vrancea (Romania) region on 6 to 30 September 2008, Romanian Reports in Physics, 64, 571-590.

Radulian, M., N. Mandrescu, E. Popescu, A. Utale and G. F. Panza GF. (1999). Seismic activity and stress field in Romania. Romanian Journal of Physics., 44, 1051-1069.

Radulian, M., N. Mandrescu, G. F. Panza, E. Popescu and A. Utale (2000). Characterization of seismogenic zones of Romania, Pure Appl. Geophys., 157, $57-77$.

Radulian, M., E. Popescu, A. Bala and A. Utale (2002). Catalog of the fault plane solutions for the earthquakes occured on the Romanian territory, Roma- 
nian Journal of Physics, 47, 663 - 670.

Radulian, M. (2014). Mechanisms of Earthquakes in Vrancea, in Encyclopedia of Earthquake Engineering, M. Beer, E. Patelli, I. Kougioumtzoglou, I. SiuKui Au (Editors), Springer-Verlag, Berlin Heidelberg, DOI 10.1007/978-3-642-36197-5_302_1.

Răileanu, V., A. Bala A., F. Hauser, C. Prodehl C. and W. Fielitz (2005). Crustal properties from $S$-wave and gravity data along a seismic refraction profile in Romania, Tectonophysics, 410, 251 - 272.

Ren, Y., G. W. Stuart, G. A. Houseman, B. Dando, C. Ionescu, E. Hegedüs, S. Radovanović, Y. Shen and South Carpathian Project Working Group (2012). Upper mantle structures beneath the CarpathianPannonian region: Implications for the geodynamics of continental collision, Earth and Planetary Science Letters, 349-350, 139-152.

Roman, C. (1973). Research note: rigid plates, buffer plates and sub-plates, Comment on 'Active Tectonics of the Mediterranean Region' by D. P. McKenzie, Geophys. J. R. Astr. Soc., 33, 359-373.

Sandu, I. and A. Zaicenko (2008). Focal mechanism solutions for Vrancea seismic area, in "Harmonization of Seismic Hazard in Vrancea Zone”, A. Zaicenco, I. Craifaleanu, I. Paskaleva (Editors), NATO Science for Peace and Security Series - C, Springer, Dordrecht, 17-46.

Săndulescu, M. (1984). Geotectonics of Romania (in Romanian), Ed. Tehnică, Bucharest, 334 pp.

Snoke, J.A., J. W. Munsey, A. G. Teague and G. A. Bollinger (1984). A programme for focal mechanism determination by combined use of polarity and SV$\mathrm{P}$ amplitude ratio data, Earthquake Note, 55, 15pp.

Tugui, A., M. Craiu, M. Rogozea, M. Popa and M. Radulian M. (2009). Seismotectonics of Vrancea (Romania) zone: the case of crustal seismicity in the foredeep area, Romanian Reports in Physics, 61, 325-334.

Wenzel, F., Achauer, U., Enescu, D., Kissling, E., Russo, R., Mocanu, V. and G. Musacchio (1998). Detailed look at final stage of plate break-off is target of study in Romania, EOS, Trans. Am. geophys. Un., 79, 589, 592-594.

*Corresponding author: Mircea Radulian,

National Institute for Earth Physics, Măgurele, Romania email: mircea@infp.ro

C 2018 by the Istituto Nazionale di Geofisica e Vulcanologia. All rights reserved. 